DOI: $10.14720 /$ aas.2016.107.1.13

Agrovoc descriptors: weeds; noxious plants; phytoplasmas; genetic techniques; pcr; genetic polymorphism; rflp; identification

Agris category code: $\mathrm{H} 60, \mathrm{~h} 20, \mathrm{f} 30$

\title{
Molecular identification of phytoplasmas associated with some weeds in West Azarbaijan province, Iran
}

\author{
Samaneh ZIBADOOST ${ }^{1}$, Mina RASTGOU ${ }^{1}$
}

Received September 13, 2015; accepted Janury 09, 2016.

Delo je prispelo 13. septembra 2015, sprejeto 09. januarja 2016.

\begin{abstract}
During field surveys in 2013 and 2014, about 14 weed plants showing phytoplasma diseases symptoms including yellowing and witches' broom were collected and tested by polymerase chain reaction (PCR) using universal primers for 16SrRNA starting by primer pairs P1/P7 in first round PCR followed by primer pair R16F2n/R16R2 in nested PCR. The detected phytoplasmas were characterized and differentiated through sequence analysis of PCR-amplified rDNA and virtual restriction fragment length polymorphism (RFLP). The phytoplasmas detected in symptomatic horseweed (Erigeron canadensis L.), common madder (Rubia tinctorum L.), Johnson grass (Sorghum halepense [L.] Pers.) and Sophora root (Sophora alopecuroides L.) were identified as members of the clover proliferation group (16SrVI group) by construction of phylogenetic trees. Further analysis by virtual RFLP classified the phytoplasmas of Erigeron canadensis L. and Sorghum halepense L. in subgroup 16SrVI-A and phytoplasmas of Rubia tinctorum L. and Sophora alpecuriodes L. in subgroup 16SrVI-D. This is the first report on the occurrence of phytoplasma diseases of weeds in west Azarbaijan, Iran.
\end{abstract}

Key words: common madder, Sophora root, Johnson grass, horseweed, nested-PCR, Urmia

\section{IZVLEČEK}

\author{
MOLEKULSKA DOLOČITEV FITOPLAZEM \\ NAJDENIH V NEKATERIH PLEVELIH V PROVINCI \\ ZAHODNI AZARBEJDŽAN, IRAN
}

Med pregledom polj, v letih 2013 in 2014, je 14 plevelnih vrst kazalo simptome okužbe s fitoplazmami kot so rumenenje in čarovniške metle. Nabrane vzorce smo analizirali z verižno reakcijo s polimerazo (PCR) $\mathrm{z}$ uporabo splošnih začetnih oligonukleotidov za 16SrRNA, začenši $\mathrm{s}$ pari začetnih oligonukleotidov P1/P7 v prvem krogu PCR analize, ki ji je sledila vgnezdena PCR anliza $\mathrm{s}$ parom začetnih oligonukleotidov R16F2n/R16R2. Odkrite fitoplazme so bile okarakterizirane in razlikovane $\mathrm{s}$ sekvenčno analizo PCR pomnožene rDNA in virtualnim polimorfizmom dolžin restrikcijskih fragmentov (RFLP). Fitoplazme, ki smo jih odkrili $\mathrm{v}$ simptomatični kanadski suholetnici (Conyza canadensis (L.) Cronq.), pravem brošču (Rubia tinctorum L.), divjem sirku (Sorghum halepense (L.) Pers.) in korenasti sofori (Sophora alopecuroides L.) so bile $\mathrm{z}$ izdelavo filogenetskega drevesa določene kot pripadnice skupine, ki povzroča proliferacijo detelje (16SrVI skupina). Nadaljnja analiza $\mathrm{z}$ virtualno klasifikacijo RFLP je fitoplazmi v kandski suholetnici in divjem sirku uvrstila v podskupino 16SrVI-A in fitoplazmi v pravem brošču in korenasti sofori v podskupino 16SrVI-D. To je prvo poročilo o pojavljanju od fitoplazem povzročenih bolezni na plevelih v zahodnem Azarbeidžanu, Iranu.

Ključne besede: pravi brošč, korenasta sophora, divji sirek, kanadska suholetnica, vgnezdena-PCR, Urmia

\footnotetext{
Department of Plant Protection, College of Agriculture, Urmia University, Urmia, Iran; Correspondence to Dr. Mina Rastgou. E-mail: m.rastgou@urmia.ac.ir/mrastgou2006@yahoo.com
} 


\section{INTRODUCTION}

Phytoplasmas are a group of wall-less phloemlimited plant pathogenic bacteria belonging to Mollicutes which have been described relative recently (Lee et al., 1998). They are associated with diseases in several hundreds of plant species, including weeds (Marcone et al., 1997). Typical symptoms include virescence/phyllody, sterility of flowers, proliferation of axillary buds resulting in witches broom growth, abnormal internodes elongation and generalized stunting (Bertaccini et al., 1996; 2014). Phytoplasmas are introduced by insect vectors (mostly leafhoppers) during feeding activity into plant sieve tube elements, from which they spread systemically through the plants (Bertaccini et al., 2014). Currently, characterization and classification of phytoplasmas are based mainly on restriction fragment length polymorphism (RFLP) and sequence analysis of 16SrDNA or other less-conserved genes, whereas detection is done mainly by polymerase chain reaction (PCR) assay (Bertaccini et al., 2014; Lee et al., 2000; Seemuller et al., 1998). Weeds serve as both a reservoir for phytoplasma infection and as reproductive hosts for the vectors (Singh and Upadhyaya, 2013). Phytoplasmas are known to cause diseases in weeds including field bindweed (Convolvulus arvensis L.), prickly lettuce (Lactuca serriola L.), Johnson grass (Sorghum halepense (L.) Pers.), bermuda grass (Cynodon dactylon (L.) Pers.), horseweed (Conyza canadensis (L.) Cronq.) and some others were reported worldwide (Arocha-Rosete and Jones, 2010; Babaie et al., 2007; Chen et al., 2003; Li et al., 2013; Marcone et al., 1997; Salehi et al., 2006; Shubhrata, 2004; Thereza and Baross, 2002; Vali Sichani et al., 2014). However little is known about phytoplasma diseases of weeds in west Azarbaijan province of Iran. The aim of this study was to verify the presence of phytoplasma diseases in symptomatic weeds in West Azarbaijan province using PCR assay. The detected phytoplasmas were characterized and classified using sequence analysis of PCR-amplified 16SrDNA and virtual gel RFLP.

\section{MATERIALS AND METHODS}

\subsection{Plant materials}

Fourteen weed plants related to 4 plant species including Johnson grass (Sorghum halepense (L.) Pers.), Canadian horseweed (Conyza canadensis. (L.) Cronquist), Sophora root (Sophora alopecuroides L.) and common madder (Rubia tinctorum L.) showing symptoms typical of phytoplasmal infection were collected during 2013 and 2014 growing seasons (Table 1) from different regions of West Azarbaijan province including Urmia, Salmas, Khoy and Mahabad cities. Asymptomatic plants were also collected and used in molecular analysis as negative controls.

\subsection{DNA Extraction}

Total DNA was extracted from $0.25 \mathrm{~g}$ of leaves and midribs according to the method described by Zhang et al (1998). Total DNA of healthy plants were extracted and used as negative controls.

\subsection{PCR Analysis and Primer Pairs}

The universal primer pair P1/P7 (Schneider et al., 1995) was employed in first round PCR to amplify a $1.8 \mathrm{kbp}$ fragment of $16 \mathrm{SrDNA}$. A 30 -fold dilution of the first round PCR product used as template for nested PCR using primer pair R16f2n/R16R2 which amplified an internal fragment of $1.2 \mathrm{kbp}$ from the 16SrDNA (Lee et al., 1993). The total volume of $20 \mu \mathrm{l}$ PCR reaction mixtures contained 20ng DNA, $0.2 \mathrm{mM}$ of each dNTP (Cinnagen, Iran), $1.6 \mathrm{mM} \mathrm{MgCl} 2,1 \mathrm{U}$ of Taq DNA polymerase (Cinnagen, Iran), $0.5 \mu 1$ of each primer pair $(20 \mathrm{pmol} / \mu \mathrm{l})$ and $1 \mathrm{X}$ polymerase buffer. The reaction mixtures were subjected to 35 cycles at the following conditions: First round PCR (35 cycles): $1 \mathrm{~min}$ ( $3 \mathrm{~min}$ for the first cycle) for denaturation step at $94^{\circ} \mathrm{C}, 1 \mathrm{~min}$ for annealing at $57^{\circ} \mathrm{C}$ and $1.5 \mathrm{~min}$ (10 $\mathrm{min}$ for the last cycle) for primer extension step at $72^{\circ} \mathrm{C}$. Second round nested PCR (35 cycles): 2 min (5 min for the first cycle) for denaturation step at $94^{\circ} \mathrm{C}, 1 \mathrm{~min}$ for annealing at $57^{\circ} \mathrm{C}$ and $2 \mathrm{~min}(10 \mathrm{~min}$ for the last cycle) for primer extension step at $72^{\circ} \mathrm{C}$. The PCR 
products were analyzed by electrophoresis in a $1 \%$ agarose gel and stained with ethidium bromide. An ultraviolet (UV) transilluminator was used to visualize DNA band.

\subsection{Sequencing and Phylogenetic Analysis}

PCR products of nested PCR were sequenced directly. Sequencing was performed by Macrogen (South Korea) on both strands. Nucleotide sequence similarity, multiple alignment and phylogenetic tree construction using the neighborjoining (NJ) method were done with MEGA5 software (Tamura et al., 2011) and subjected to bootstrap analysis using 500 replicates. The Acholeplasma laidlawii isolate was used as outgroup.

\subsection{Virtual RFLP Analysis}

Virtual RFLP analysis using iPhyclassifier (Zhao et al., 2009) was used to determine 16Sr group and subgroup affiliation of the detected phytoplasmas. RFLP profiles of detected phytoplasmas were compared to those of $16 \mathrm{SrVI}$-subgroups A, B, C, D, E, F, H using AluI, BamHI, BfaI, BstUI, DraI, EcoRI, HaeIII, HhaI, HinfI, HpaI, HpaII, KpnI, Sau3AI, MseI, RsaI, SspI and TaqI enzymes.

\section{RESULTS AND DISCUSSION}

During growing seasons of 2013 and 2014, fourteen weed samples with phytoplasma symptoms were collected from different parts of West Azarbaijan province, Iran. The symptoms varied with the host plant and the most characteristic symptoms were witches' broom, leaf malformation, little leaf and yellowing (the symptoms are summarized in Table 1 and some symptomatic plants were shown in Fig.1).

Table 1: Weeds showing phytoplasma-like symptoms

\begin{tabular}{|c|c|c|c|c|c|c|c|}
\hline $\begin{array}{l}\text { Common } \\
\text { name }\end{array}$ & Scientific name & $\begin{array}{l}\text { Plant } \\
\text { family }\end{array}$ & symptoms & $\begin{array}{l}\text { No of } \\
\text { samples }\end{array}$ & $\begin{array}{l}\text { Place of } \\
\text { sampling }\end{array}$ & $\begin{array}{l}\text { Date of } \\
\text { collection }\end{array}$ & $\begin{array}{l}\text { Latitude, } \\
\text { Altitude } \\
\text { and height } \\
\text { above level } \\
\text { sea of the } \\
\text { city }\end{array}$ \\
\hline $\begin{array}{l}\text { Johnson } \\
\text { grass }\end{array}$ & $\begin{array}{l}\text { Sorghum } \\
\text { halepense } \\
\text { Pers. }\end{array}$ & Gramineae & Little leaf & 2 & Salmas & $\begin{array}{l}2 \text { June } \\
2014\end{array}$ & $\begin{array}{l}38^{\circ} \mathrm{N}, \\
44^{\circ} \mathrm{E}, 1406 \\
\text { meters }\end{array}$ \\
\hline $\begin{array}{l}\text { Canadian } \\
\text { horseweed }\end{array}$ & $\begin{array}{l}\text { Conyza canadensis } \\
\text { (L.)Cronq. }\end{array}$ & Asteraceae & $\begin{array}{l}\text { Leaf } \\
\text { malformation, } \\
\text { and witches } \\
\text { broom }\end{array}$ & 6 & Khoy & $\begin{array}{l}17 \text { June } \\
2013\end{array}$ & $\begin{array}{l}38^{\circ} \quad \mathrm{N}, \\
44^{\circ} \mathrm{E}, 1139 \\
\text { meters }\end{array}$ \\
\hline $\begin{array}{l}\text { Sophora } \\
\text { root }\end{array}$ & $\begin{array}{l}\text { Sophora } \\
\text { alopecuroides L. }\end{array}$ & Fabaceae & $\begin{array}{l}\text { Yellowing } \\
\text { and little leaf }\end{array}$ & 2 & $\begin{array}{l}\text { Abajaloo- } \\
\text { Urmia }\end{array}$ & $\begin{array}{l}21 \text { July } \\
2014\end{array}$ & $\begin{array}{l}37^{\circ} \quad \mathrm{N}, \\
45^{\circ} \mathrm{E}, 1362 \\
\text { meters }\end{array}$ \\
\hline $\begin{array}{l}\text { Common } \\
\text { madder }\end{array}$ & Rubia tinctorum L. & Rubiaceae & Little leaf & 4 & Mahabad & $\begin{array}{l}20 \text { July } \\
2013\end{array}$ & $\begin{array}{lr}36^{\circ} & \mathrm{N}, \\
45^{\circ} \mathrm{E}, & 1304 \\
\text { meters }\end{array}$ \\
\hline
\end{tabular}




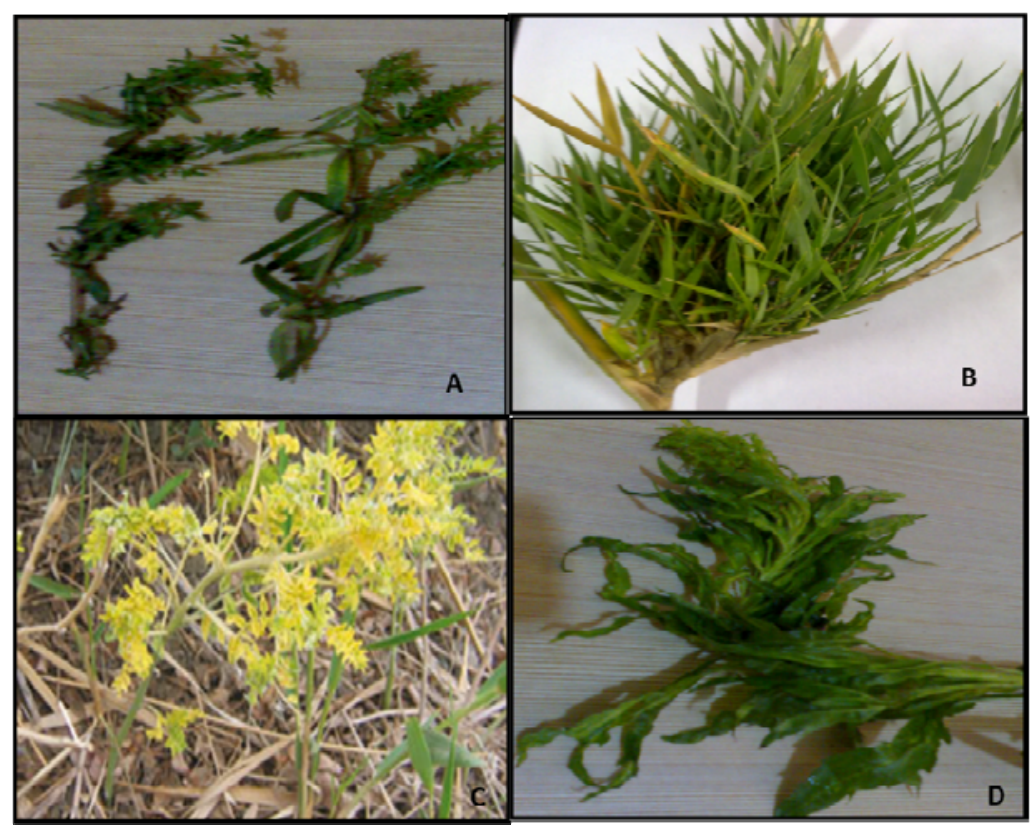

Figure 1: Weeds with phytoplasma-like symptoms in West Azarbaijan province. A-Common madder showing little leaf, B- Johnson grass with little leaf symptoms, C- Sophora root with yellowing and little leaf symptoms, DCanadian horseweed showing leaf malformation and witches' broom.

DNA fragments of approximately $1.8 \mathrm{kbp}$ and $1.25 \mathrm{kbp}$ were amplified using phytoplasma universal primer pairs, P1/P7 and R16f2n/R16R2 in first round and nested PCR, respectively from Johnson grass, Canadian horseweed, Sophora root and common madder. Neither by direct nor by nested PCR were DNA amplified form other weeds tested in this survey and from asymptomatic plants. The nucleotide sequences of the phytoplasmas detected in four plants (Johnson grass, Sophora root, Canadian horseweed and common madder) were deposited in GenBank (with accession numbers of KT807469, KT807470, KT807471 and KT807472, respectively). BLAST search showed that the 16SrDNA sequences of four detected phytoplasmas shared the highest homology (99\%) to members of the 16SrVI group 'Candidatus Phytoplasma trifolii'. Computer-stimulated restriction analysis were carried out on R16f2n/R16R2 sequences from Johnson grass, Canadian horseweed, Sophora root and common madder together with 12 reference phytoplasmas and seven representative strains belonging to 16SrVI subgroups (A, B, C, D, E, F, H). Comparison of virtual gel plotted images revealed that RFLP patterns of common madder (Ruph) and Sophora root (Tph) were most similar to periwinkle little leaf, representative of $16 \mathrm{SrVI}-\mathrm{D}$ subgroup and RFLP patterns of Canadian horseweed (Pph) and Johnson grass (Nph) were most similar to clover proliferation, representative of 16SrVI-A (Fig. 2). Phylogenetic analysis of sequences presented in this survey with 19 phytoplasmas from GenBank clustered phytoplasmas detected on Johnson grass, Canadian horseweed, Sophora root and common madder with phytoplasmas of 16SrVI group (Fig.3). 


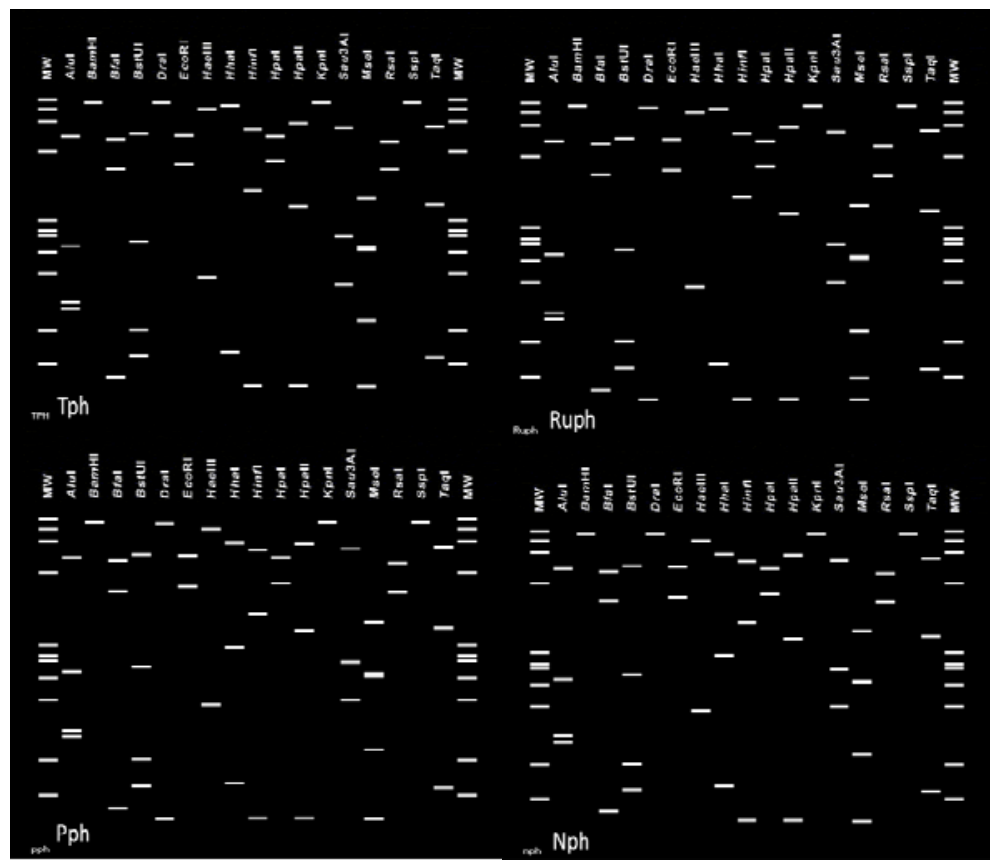

Figure 2: Virtual restriction fragment length polymorphism (RFLP) pattern of $\mathrm{R}_{16} \mathrm{~F}_{2 \mathrm{n}} / \mathrm{R}_{16} \mathrm{R}_{2}$ PCR product sequence from Sophora root (Tph), common madder (Ruph), Canadian horseweed (Pph), and Johnson grass (Nph) phytoplasmas. Restriction sites for the 17 restriction enzymes were used in the simulated digestions: AluI, BamHI, BfaI, BstUI, DraI, EcoRI, HaeIII, HhaI, HinfI, HpaI, HpaII, KpnI, Sau3AI, MseI, RsaI, SspI and TaqI.

Two phytoplasmas which were previously reported from Canadian horseweed exhibiting yellowing and witches' broom symptoms were classified in 16SrI (SrI-A) (Lee et al., 2000) and 16SrVII groups (Thereza and Baross, 2002), respectively. This is the first report of little leaf symptom on Canadian horseweed that is classified in phytoplasma 16SrVI group. The phytoplasma which causes yellowing on Johnson grass, detected in our survey, was classified in 16SrVI group. Previously, on Johnson grass exhibiting yellowing Arocha-Rosete and Jones (2010) and Singh and Upadhyaya (2013) found phytoplasmas of 16SrXXIV-A and 16SrXII groups, respectively. Sophora root with little leaf and yellowing symptoms was classified in 16SrVI group in this study. Previous reports of phytoplasmas affecting Sophora species include a 16SrXII phytoplasma associated with $S$. japonica L (Styphnolobium japonicum (L.) Schott.) yellows in China (Duduk et al., 2010), 'Ca. Phytoplasma ziziphi' in China associated with witches' broom and a 16SrI 'Ca.Phytoplasma asteris' associated with Sophora root yellows (Yu et al., 2012; Chen et al., 2013). Recently Allahverdi et al. (2014) reported a 16SrXII phytoplasma association with $S$. alopecuroides from Firooz-koh (Tehran Province, Iran) with leaf yellowing, little leaf and stunting symptoms. The association of a phytoplasma belonging to $16 \mathrm{SrVI}$ was previously established in Sophora root (Sophora alopecuroides L.) exhibiting yellowing and witches' broom symptoms from China (Li et al., 2013). There is no data on common madder phytoplasma infection and to our knowledge it is the first report of phytoplasma (16SrVI group) infection of common madder. 


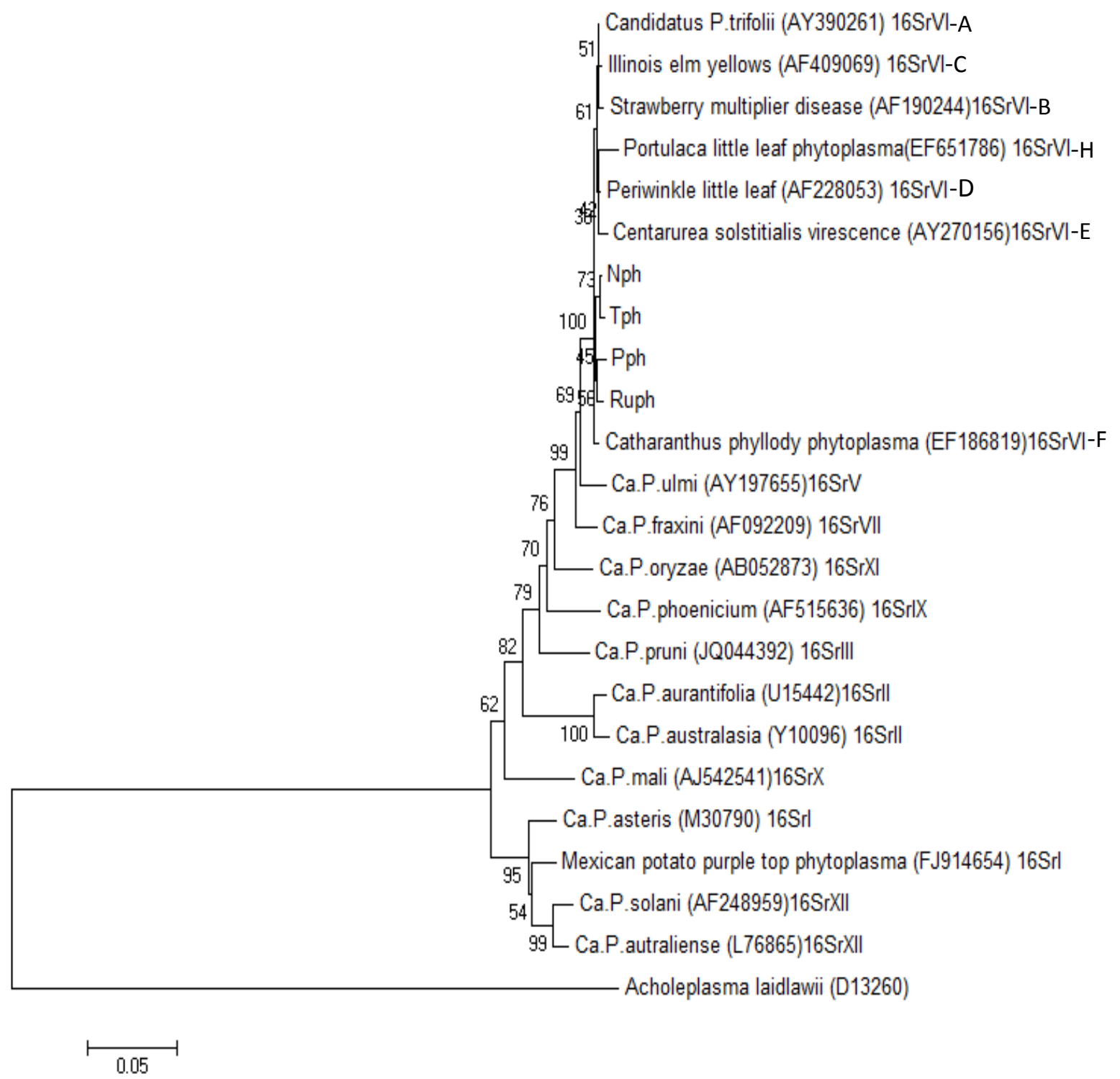

Figure 3: Phylogenetic tree constructed by the neighbor joining method of 16SrRNA gene sequences from 19 phytoplasma and phytoplasmas identified from Sophora root (Tph), common madder (Ruph), Canadian horseweed (Pph), and Johnson grass ( Nph) and Acholeplasma laidlawii as outgroup. Numbers at the nodes are bootstrap values based on 500 repetitions. GenBank accession numbers for sequences are given in parentheses.

\section{CONCLUSIONS}

To date, phytoplasmas have been documented in more than 100 weed plant species. Phytoplasmas cause diseases on several weeds which result in serious threat as a source of alternative natural host for the spread of phytoplasma pathogen to other economically important plants, thereby creating a chance of causing severe losses. Detection of phytoplasma associated with diseases of weed crops is very important to check the possibility of further spread of their diseases to other plants. Results of this study can facilitate further works on ecology, epidemiology and diversity of phytoplasmas in Iran. This is the first report on the occurrence of phytoplasma diseases on weeds in West Azarbaijan province, Iran. 


\section{ACKNOWLEDGEMENT}

The authors want to thank Ms. Asghari Tazehkand for her technical advices and supports and Dr. Majid Siampour for his technical advices and critical reading and improvement of the manuscript.

\section{REFERENCES}

Allahverdi T, Rahimian H, Babaeizad V. 2014. First report of a Candidatus phytoplasma solani isolate affecting Sophora alopecuroides in Iran. New Disease Reports, 30: 22. DOI: 10.5197/j.20440588.2014.030.022

Arocha-Rosete Y, Jones P. 2010. Phytoplasma diseases of the Gramineae. In: Phyllis GW, Jones P. (eds) Phytoplasma, genomes, plant host and vectors. London, UK. 170-187.

Babaie G, Khatabi B, Bayat H, Rastgou M, Hosseini A, Salekdeh GH. 2007. Detection and characterization of phytoplasma infecting of ornamental and weed plants in Iran. Journal of Phytopathology, 155, 6: 368-372. DOI: 10.1111/j.1439-0434.2007.01247.x

Bertaccini A, Duduk B, Paltrinieri S, Contaldo N. 2014. Phytoplasmas and phytoplasma diseases: a severe threat to agriculture. American Journal of Plant Science, $\quad 5: \quad 1763-1788 . \quad$ DOI: 10.4236/ajps.2014.512191

Bertaccini A, Bellardi MG, Vibio M. 1996. Virus diseases of ornamental shrubs. X. Euphorbia pulcherrima Willd. infected by viruses and phytoplasmas. Phytopathologia Mediterranea, 35: 129-132.

Chen XF, Liang YC, Chen N, Su WM, Xiao H, Wang X, Zhu XP. 2013. Molecular identification of a phytoplasma associated with Sophora root yellows. Forest Pathology, 43: 415-421. DOI: 10.1111/efp. 12048

Duduk B, Tian J, Contaldo N, Fan X, Paltrinieri S, Chen Q, Zhao Q, Bertaccini A. 2010. Occurrence of phytoplasmas related to stolbur and to 'Candidatus Phytoplasma japonicum' in woody host plants in China. Journal of Phytopathology, 158: 100-104. DOI: $10.1111 / j .1439-0434.2009 .01586 . x$

Lee IM, Gundersen DE, Bertaccini A. 1998. Phytoplasma: ecology and genomic diversity. Phytopathology, 88: 1359-1366. DOI: 10.1094/PHYTO.1998.88.12.1359

Lee IM, Davis RE, Gundersen DE. 2000. Phytoplasma: phytopathogenic mollicutes. Annual Review of Microbiology, 54: 221-255. DOI: 10.1146/annurev.micro.54.1.221
Lee IM, Hammond RW, Davis RE, Gundersen DE. 1993. Universal amplification and analysis of pathogen 16SrDNA for classification and identification of mycoplasma-like organisms. Phytopathology 83: 834-842. DOI: 10.1094/Phyto83-834

Li CL, Du YJ, Xiang BC. 2013. Molecular detection and identification of Sophora alopecuroides witches' broom phytoplasma. Xinjiang Agricultural Science, 50: 92-99.

Marcone C, Ragozzino A, Seemuller E. 1997. Detection and identification of phytoplasmas infecting vegetable, ornamental and foliage crops in southern Italy. Journal of Plant Pathology, 79: 211-217.

Salehi M, Izadpanah K, Nejat N. 2006. A new phytoplasma infecting lettuce in Iran. Plant Disease, 90: 247. DOI: 10.1094/PD-90-0247C

Schneider B, Seemuller E, Smart CD, Kirkpatrik BE. 1995. Phylogenetic classification of plant pathogenic mycoplasma-like organisms or phytoplasmas. In: Razin S, Tully JG (eds.). Molecular and Diagnostic Procedures in Mycoplasmology, 369-380. DOI: 10.1016/b978012583805-4/50040-6

Seemuller E, Marcone C, Lauer U, Ragozzino A, Goschl M. 1998. Current status of molecular classification of the phytoplasmas. Plant Pathology, 80: $3-26$

Shumbhrata RM. 2004. Mulicutes and Plant Diseases. New Delhi. Discovery Publishing House.

Singh N, Upadhyaya PP. 2013. Analysis of medicine weeds associated with phytoplasma by morphological characters. International Journal of Medicinal Plants and Alternative Medicine, 2,1: 001-004.

Tamura K, Peterson D, Peterson N, Stecher G, Nei M, Kumar S. 2011. MEGA5: Molecular evolutionary genetics analysis using maximum likelihood, Evolutionary distance, and maximum parsimony methods. Molecular Biology Evolution, 28: 27312739. DOI: $10.1093 / \mathrm{molbev} / \mathrm{msr} 121$

Thereza S, Baross L. 2002. Erigeron witches' broom in Brazil represents new subgroup VII. The Ash

Acta agriculturae Slovenica, 107 - 1, marec 2016 
yellows phytoplasma group. Phytopathology, 86: 1142-1148.

Yu ZC, Cao Y, Zhang Q, Deng DF, Liu ZY. 2012. 'Candidatus Phytoplasma ziziphi' associated with Sophora japonica witches' broom disease in China. Journal of General Plant Pathology, 78: 298-300. DOI: $10.1007 / \mathrm{s} 10327-012-0385-7$

Vali Sichani F, Bahar M, Zirak L. 2014. Characterization of phytoplasma related to aster yellows group infecting annual plants in Iran, based on the studies of $16 \mathrm{~S}$ rRNA and rp genes. Journal of Plant Protection Research, 54, 1: 1-8. DOI: 10.2478/jppr-2014-0001
Zhang Y, Uyemoto JK, Kirkpatrick BC. 1998. A smallscale procedure for extracting nucleic acids from woody plants infected with various phytopathogens for PCR assay. Journal of Virological Methods, 71: 45-50. DOI: 10.1016/S0166-0934(97)00190-0

Zhao Y, Wei W, Lee IM, Shao J, Suo X, Davis RE. 2009. Construction of an interactive online phytoplasma classification tool, iPhyClassifier, and its application in analysis of the peach X-disease phytoplasma group (16SrIII). International Journal of Systematic and Evolutionary Microbiology, 59: 2582-2593. DOI: 10.1099/ijs.0.010249-0 